University of Nebraska - Lincoln

DigitalCommons@University of Nebraska - Lincoln

Biological Systems Engineering: Papers and

Publications

Biological Systems Engineering

1998

Relationships Among Grain Sorghum Quality Factors

Roberto A. Buffo

University of Nebraska-Lincoln

Curtis L. Weller

University of Nebraska-Lincoln, cweller1@unl.edu

Anne M. Parkhurst

University of Nebraska-Lincoln

Follow this and additional works at: https://digitalcommons.unl.edu/biosysengfacpub

Part of the Biological Engineering Commons

Buffo, Roberto A.; Weller, Curtis L.; and Parkhurst, Anne M., "Relationships Among Grain Sorghum Quality Factors" (1998). Biological Systems Engineering: Papers and Publications. 107.

https://digitalcommons.unl.edu/biosysengfacpub/107

This Article is brought to you for free and open access by the Biological Systems Engineering at DigitalCommons@University of Nebraska - Lincoln. It has been accepted for inclusion in Biological Systems Engineering: Papers and Publications by an authorized administrator of DigitalCommons@University of Nebraska Lincoln. 


\title{
Relationships Among Grain Sorghum Quality Factors ${ }^{1}$
}

\author{
Roberto A. Buffo, ${ }^{2,3}$ Curtis L. Weller, ${ }^{2,4}$ and Anne M. Parkhurst ${ }^{5}$
}

ABSTRACT

Cereal Chem. 75(1):100-104

\begin{abstract}
Correlations among grain sorghum quality factors (proximate composition, physical properties, and water absorption properties) were evaluated. Samples of 46 commercial hybrids ( 24 and 22 from crop years 1993 and 1994) were analyzed for starch, protein, crude free fat, test weight, absolute density, 1,000 kernel weight, percent kernel abraded, water absorption index, initial water absorption rate, and moisture saturation point. Test weight, absolute density, and percent kernel abraded were positively correlated among themselves $(r>0.5)$. Protein was negatively correlated with both test weight and absolute density $(r<-0.5)$, while moisture
\end{abstract}

saturation point showed negative correlations with test weight, absolute density, 1,000 kernel weight, and percent kernel abraded $(r<-0.4)$. Principal component factor analysis through the covariance matrix explained $95 \%$ of the total variation of quality factors among hybrids (two factors), and, through the correlation matrix, $85 \%$ of the total variation (five factors). Water absorption rate decreased with increasing starch content of grain sorghum kernels as water absorption rate increased and amount of water for saturation decreased with softening of kernels.
Grain sorghum (Sorghum bicolor L. Moench) is an important crop in semiarid regions because of its drought resistance (Watson 1970). Lately, there has been increased interest in sorghum with respect to its potential for starch production because its wet-milling process is similar to that of corn (Subramanian et al 1994). There is also interest in the utilization of sorghum by-products such as surface wax and kafirin, the alcohol-soluble (prolamin) protein fraction.

In contrast to rice and wheat, consumption of sorghum as a staple food in arid regions of Africa and Asia is so diverse that no single criterion of quality can be identified. This has hindered progress of plant breeders in selecting agronomically improved sorghum hybrids with acceptable grain quality (Cagampang and Kirleis 1984).

Subramanian and Jambunathan (1981) established relationships among physicochemical characteristics of 45 sorghum hybrids. The 100 grain weight associated negatively with protein and positively with amylose content. Protein content showed a strong negative correlation with starch and water-soluble amylose contents in the grain and was positively related to water-soluble protein and ash contents. Starch content was positively associated with water-soluble amylose. Soluble sugars correlated positively with protein and negatively with amylose.

Cagampang and Kirleis (1984) used selected physical and chemical measurements to determine grain quality of 15 sorghum hybrids differing widely in degree of hardness and vitreousness. Results of adhesion test, back-extrusion test, alkali gel stiffness test, and weight ratio of cooked to uncooked grain were strongly correlated with grain vitreousness. Fat, ash, total sugars, and water-soluble proteins were negatively correlated with hardness, whereas kafirin and amylose contents were positively correlated with vitreousness.

Maxson et al (1971) studied 11 sorghum varieties of diverse genetic background with regard to the effect of milling time and physical properties of the grain on dry-milling performance. Endosperm texture (relative proportions of corneous to floury) was the property most highly correlated with milling yield. Density and hardness correlated inversely with milling yield. Endosperm texture was negatively correlated with hardness, test weight and density.

\footnotetext{
${ }^{1}$ Journal Series no. 11781. Agricultural Research Division, Institute of Agriculture and Natural Resources, University of Nebraska-Lincoln.

${ }^{2}$ Graduate research assistant and associate professor, respectively, Departments of Biological Systems Engineering and Food Science and Technology, University of Nebraska-Lincoln, Lincoln, NE 68583-0726.

${ }^{3}$ Currently, graduate research assistant, Department of Food Science and Nutrition, University of Minnesota, St. Paul, MN 55108.

${ }^{4}$ Corresponding author. E-mail: bsen004@unlvm.unl.edu

${ }^{5}$ Professor and Head, Department of Biometry, University of Nebraska-Lincoln, Lincoln, NE 68583-0712.
}

Publication no. C-1998-0107-03R.

() 1998 by the American Association of Cereal Chemists, Inc.
Munck et al (1981) focused on correlations between chemical components and kernel parameters associated with dry-milling characteristics, such as Vickers' hardness, number of dehullings to $75 \%$ yield, percent soft endosperm, percent kernels of more than $40 \%$ softness, kernel size, and form factor. Vickers' hardness and number of dehullings to $75 \%$ yield were positively correlated with starch content and negatively correlated with fiber, fat, and ash, indicating a greater precision in the separation of botanical parts when the seed was harder. Percent soft endosperm and percent seeds with $>40 \%$ softness followed the same pattern, but with opposite signs.

The objective of this study was to increase the understanding of relationships among grain sorghum quality factors (proximate composition, physical properties, and water absorption properties) by studying hybrids typically grown in Nebraska and Kansas of the midwestern United States, specifically properties of grain sorghum related to water uptake were of interest as they relate to wet-milling. Factors analyzed included protein, crude free fat, starch, test weight, kernel density, kernel hardness, 1,000 kernel weight (TKW), water absorption index (WAI), initial water absorption rate (IWAR), and moisture saturation point (MSP).

\section{MATERIALS AND METHODS}

\section{Grain Sorghum Samples}

During the 1993 crop year, 24 grain sorghum commercial hybrids were grown in and harvested from a test plot in Gage County, NE. From the same location, 22 sorghum hybrids were harvested in 1994, creating a total of 46 hybrids. Rainfall and average air temperature during the 183-day growing season ending on September 30, 1993, were $157 \%$ of normal and $0.7^{\circ} \mathrm{C}$ less than normal, respectively. In contrast, the 1994 rainfall and temperature were $110 \%$ of normal and $0.6^{\circ} \mathrm{C}$ greater than normal, respectively (High Plains Climate Center, University of Nebraska, personal communication 1997).

The hybrids were considered representative of sorghums commonly grown in the Nebraska and Kansas. In this regard, genetic diversity of sample set was limited. To limit effects of hot-air drying and mechanical harvesting on grain properties, sorghum was harvested by hand, air-dried (ambient, $20-25^{\circ} \mathrm{C}$ ) to $13-14 \%$ (wb) moisture content and then threshed in a laboratory thresher. Threshed grain was cleaned over a $6.35-\mathrm{mm}$ screen in a dockage tester (Carter-Day, CEA, Minneapolis, MN) and stored at $4^{\circ} \mathrm{C}$ until needed for chemical analysis or physical testing.

\section{Moisture Content}

The ASAE moisture measurement method $\$ 352.2$ for unground grain and seeds (ASAE 1992) was used to determine moisture content of whole grain. Chemical composition values were 
adjusted to percent dry basis $(\% \mathrm{db})$ according to moisture content results. Physical properties were not adjusted for moisture, which would have required development of individual equations. Nevertheless, sorghum from both harvesting seasons had nearly identical average moisture values following drying: $13.95 \pm 0.33 \%$ and $13.80 \pm 0.43 \%$ for the years 1993 and 1994 , respectively, which practically eliminated any possible significant difference between years due to moisture content.

\section{Proximate Analysis}

Starch content was determined in triplicate according to the Approved Method 76-12 (AACC 1995). Protein content was determined in duplicate by the Corn Refiners Association macroKjeldahl method A-18 (CRA 1986) using the Tecator Kjeltec System (Tecator, Hoganäs, Sweden). Nitrogen conversion factor was 6.25. Crude free fat was measured in duplicate according to AOAC method 922.05 (AOAC 1984).

\section{Physical Properties}

Test weight, a measure of grain bulk density, was determined according to the USDA Federal Grain Inspection Service method (FGIS 1988) using a grain analysis computer (II, Dickey-john Corp., Auburn, IL). Three readings were obtained per hybrid and averaged. Values were converted from $\mathrm{lb} / \mathrm{bu}$ to $\mathrm{kg} / \mathrm{m}^{3}$.

Absolute kernel density (density) was determined according to the air-comparison pycnometer method described by Thompson and Isaacs (1967). Sorghum grain $(20 \mathrm{~g})$ was weighed to $\pm 0.001 \mathrm{~g}$. Volume was measured with a multi-volume pycnometer (1305, Micromeritics, Norcross, GA). One sample was taken per hybrid, and its volume measured in quintuplicate. Absolute density was computed as the ratio between exact sample weight and mean volume.

The TKW, a relative measure of grain size, was determined for each sample by weighing 100 randomly selected, unbroken kernels to within $0.01 \mathrm{~g}$ and multiplying the result by 10 . Three replicates per hybrid were obtained.

Grain hardness was determined by using the tangential abrasive dehulling device (TADD) model 4e-220, Venables Machine Works Ltd., Saskatoon, SK, Canada) as described by Reichert et al (1981) and Oomah et al (1981). Grain sorghum samples of $40 \pm$ $0.1 \mathrm{~g}$ were placed in cups of the TADD and abraded for $4 \mathrm{~min}$. Hardness was then characterized by the percent abraded (\%A) as:

$\% \mathrm{~A}=100-[($ final weight/initial weight $) \times 100]$

Three readings were taken per hybrid and averaged.

\section{Water Absorption Properties}

Water absorption properties were measured according to three different criteria: WAI, IWAR, and MSP. Hsu et al (1983) origi- nally defined the corresponding methodologies for soybean, while Dorsey-Redding et al (1991) adapted them for corn. For applying these parameters to grain sorghum, it was necessary to redefine water-soaking times according to differences in kernel size and shape. Thus, a moisture absorption curve was obtained for two hybrids: DeKalb 48 and Asgrow A504 (1993 crop year). Twelve beakers per hybrid, each one containing $10 \pm 0.05 \mathrm{~g}$ of grain and $200 \mathrm{~mL}$ of distilled water, were placed in a waterbath at $50^{\circ} \mathrm{C}$. This temperature, instead of $30^{\circ} \mathrm{C}$ used by Hsu et al (1983) and Dorsey-Redding et al (1991), was chosen with the purpose of subsequently studying relationships between grain quality factors and wet-milling characteristics of grain sorghum (steeping temperature for grain sorghum wet-milling was $50^{\circ} \mathrm{C}$ ). Beakers were removed from the waterbath after $0.25,0.50,0.75,1,1.5,2,2.5,3,4,5,7$, 13 , and $20 \mathrm{hr}$. Kernel surfaces were blotted dry and fractional weight increases were measured as the relationship between final and initial sample weights. Figure 1 depicts the two moisture absorption curves obtained. Expectedly, they were saturation curves with a rapid, nearly linear water absorption during the first hour, a saturation point at $\approx 7-8 \mathrm{hr}$ and a middle, average point (point of $\approx 50 \%$ saturation at $\approx 2 \mathrm{hr}$ ). Water absorption properties were defined and measured, modifying the original procedure by Hsu et al (1983).

WAI is a measure of the amount of water absorbed by kernels in a 2 -hr period. In this test, $10 \pm 0.05 \mathrm{~g}$ of sorghum grain were placed in a beaker containing $200 \mathrm{~mL}$ of distilled water, which, in turn, was placed in a $50^{\circ} \mathrm{C}$ waterbath. After $2 \mathrm{hr}$, kernel surfaces were blotted dry and fractional weight increases were measured as previously indicated. Two replicates per sample were obtained.

IWAR is the gain in moisture content over the first hour of steeping. In this method, fractional weight increase was measured after $0.25,0.50,0.75$ and $1 \mathrm{hr}$ of steeping $10 \pm 0.05 \mathrm{~g}$ of grain in a beaker containing $200 \mathrm{~mL}$ of distilled water, which, in turn, was placed in a $50^{\circ} \mathrm{C}$ waterbath. IWAR was estimated by the corresponding slope of the gain in moisture content versus time linear curve. One assay was performed per hybrid. Total regression coefficients were highly significant for the linear character of plotted data ranging between 0.92 and 0.99 . All curves showed a positive $y$-intercept value, indicating that an instantaneous water intake (time 0 ) at the pericarp level occurred as previously reported for wheat (Chung et al 1961) and for corn and sorghum (Fan et al 1962) kernels.

MSP is the maximum amount of moisture that grain can absorb before its seed coat ruptures as compared to the initial weight of the grain. It was calculated by measuring the fractional weight increase after steeping $10 \pm 0.05 \mathrm{~g}$ of grain for 7 and $8 \mathrm{hr}$ at $50^{\circ} \mathrm{C}$ and averaging these two values. One assay was performed per hybrid.

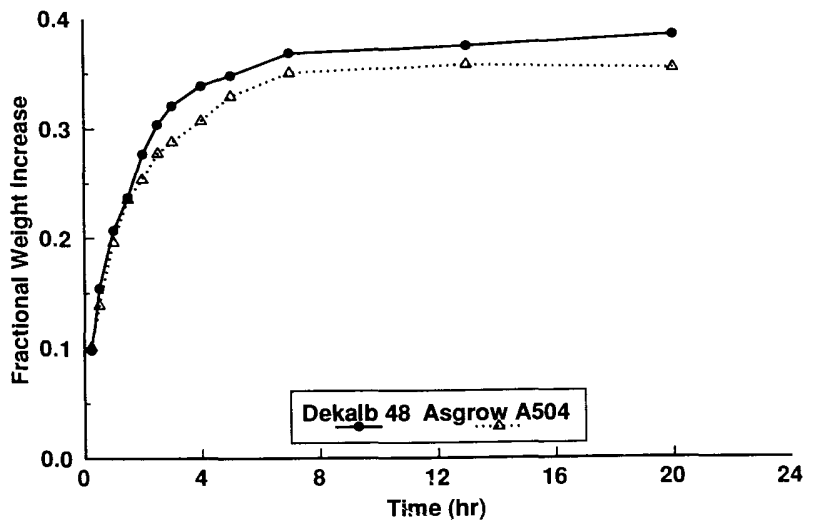

Fig. 1. Moisture absorption curves for kernels of two grain sorghum hybrids (1993 crop year).
TABLE I

Simple Statistics ${ }^{2}$ for Grain Sorghum Quality Factors (46 Hybrids from 1993 and 1994 Crop Years)

\begin{tabular}{lccc}
\hline Factors $^{\mathbf{b}}$ & Mean \pm SD & Range & CV $(\%)$ \\
\hline Starch $(\% \mathrm{db})$ & $73.12 \pm 2.73$ & $69.11-77.90$ & 3.73 \\
Protein $(\% \mathrm{db})$ & $10.52 \pm 0.71$ & $8.98-12.14$ & 6.75 \\
Crude free fat $(\% \mathrm{db})$ & $3.97 \pm 0.30$ & $3.44-4.90$ & 7.56 \\
Test weight $\left(\mathrm{kg} / \mathrm{m}^{3}\right)$ & $755.44 \pm 14.64$ & $725.97-792.90$ & 1.94 \\
Density $\left(\mathrm{g} / \mathrm{cm}^{3}\right)$ & $1.347 \pm 0.016$ & $1.317-1.392$ & 1.19 \\
TKW $(\mathrm{g})$ & $30.21 \pm 2.79$ & $24.88-35.88$ & 9.23 \\
\%A & $59.49 \pm 6.53$ & $48.63-73.93$ & 10.98 \\
WAI & $0.257 \pm 0.021$ & $0.215-0.306$ & 8.17 \\
IWAR $\left(\mathrm{hr}^{-1}\right)$ & $0.123 \pm 0.021$ & $0.076-0.160$ & 17.07 \\
MSP & $0.369 \pm 0.016$ & $0.339-0.405$ & 4.34 \\
\hline
\end{tabular}

a $\mathrm{SD}=$ standard deviation, $\mathrm{CV}=$ coefficient of variation.

b $\mathrm{TKW}=1,000$ kernel weight, $\% \mathrm{~A}=$ percent kernel abraded, $\mathrm{WAI}=$ water absorption index, IWAR = initial water absorption rate, and MSP = moisture saturation point. 
TABLE II

Correlation Coefficients $(r)^{a}$ Among Grain Sorghum Quality Factors (46 Hybrids from 1993 and 1994 crop years)

\begin{tabular}{|c|c|c|c|c|c|c|c|c|c|}
\hline Factors $^{b}$ & Starch & Protein & Fat & Test Wt & Density & TKW & $\% \mathbf{A}$ & WAI & IWAR \\
\hline Protein & ns & & & & & & & & \\
\hline Fat & ns & ns & & & & & & & \\
\hline Test weight & ns & $-0.53 * *$ & ns & & & & & & \\
\hline Density & ns & $-0.53 * *$ & ns & $0.86^{* *}$ & & & & & \\
\hline TKW & ns & ns & ns & ns & $0.34^{*}$ & & & & \\
\hline$\% \mathrm{~A}$ & ns & ns & ns & $0.52 * *$ & $0.62 * *$ & $0.32 *$ & & & \\
\hline WAI & ns & ns & ns & ns & ns & ns & ns & & \\
\hline IWAR & $-0.58 * *$ & ns & $0.32 *$ & ns & ns & ns & ns & ns & \\
\hline MSP & ns & ns & ns & $-0.60^{* *}$ & $-0.65^{* *}$ & $-0.45^{* *}$ & $-0.62 * *$ & ns & ns \\
\hline
\end{tabular}

${ }^{a} \mathrm{~ns}=$ not significant; $*$ significant at 0.05 level; ${ }^{* *}=$ significant at 0.01 level.

${ }^{\mathrm{b}} \mathrm{TKW}=1,000$ kernel weight, $\% \mathrm{~A}=$ percent kernel abraded, WAI = water absorption index, IWAR $=$ initial water absorption rate, and MSP $=$ moisture saturation point.

TABLE III

Loadings for Rotated Factors of the Covariance Matrix for Grain Sorghum Quality Factors ${ }^{\mathrm{a}, \mathrm{b}}$

\begin{tabular}{lrc}
\hline Factors $^{\mathbf{c}}$ & Factor $\mathbf{1}$ & Factor 2 \\
\hline Eigenvalue & 228.66 & 30.41 \\
Proportion & 83.85 & 11.15 \\
Cumulative proportion & 83.85 & 95.00 \\
Starch & 0.04 & $-\mathbf{0 . 4 2}$ \\
Protein & $-\mathbf{0 . 5 3}$ & 0.24 \\
Crude free fat & -0.06 & 0.23 \\
Test weight & $\mathbf{0 . 9 9}$ & -0.03 \\
Density & $\mathbf{0 . 8 7}$ & 0.18 \\
TKW & 0.28 & 0.24 \\
\%A & $\mathbf{0 . 5 5}$ & $\mathbf{0 . 8 3}$ \\
WAI & 0.05 & 0.11 \\
IWAR & 0.06 & $\mathbf{0 . 3 3}$ \\
MSP & $\mathbf{- 0 . 6 2}$ & $\mathbf{- 0 . 3 5}$ \\
\hline
\end{tabular}

a Correlation coefficients $(r)$ characterize the influence of each quality factor in the corresponding rotated factor. Bold entries are the most significant coefficients.

${ }^{b}$ Factors 1 and 2 are endosperm matrix protein composition and endosperm starch factor, respectively.

c $\mathrm{TKW}=1,000$ kernel weight, $\% \mathrm{~A}=$ percent kernel abraded, $\mathrm{WAI}=$ water absorption index, IWAR = initial water absorption rate, and MSP = moisture saturation point.

\section{Statistical Analysis}

The Statistical Analysis System (SAS Institute, Cary, NC)) was used to analyze collected data. Means, standard deviations, ranges, and coefficients of variation were computed with SAS Proc Means. Simple correlation coefficients $(r)$ among all quality factors were computed with SAS Proc Corr. Two principal component factor analyses (Johnson and Wichern 1992) with varimax rotation were performed by using SAS Proc Factor. One analysis used the covariance matrix and the other used the correlation matrix.

\section{RESULTS AND DISCUSSION}

Based on the statistics for the quality factors (Table I), the sorghum hybrids evaluated were characterized as producing mediumsized, moderately dense kernels with soft endosperm, intermediate-to-low protein content, and high starch content. All of the factors, except for protein content, fell into the corresponding ranges previously reported by Maxson et al (1971), Subramanian and Jambunathan (1981), and Serna-Saldivar and Rooney (1995). Mean protein content in this study was at least $10-15 \%$ lower than the values reported by Maxson et al (1971), and Serna-Saldivar and Rooney (1995), most likely due to differences in growing conditions and genetics.

Among proximal composition factors, protein and fat had wider variability than starch. Test weight and absolute density values were quite close among hybrids, whereas TKW and \%A had high
TABLE IV

Loadings for Rotated Factors of the Correlation Matrix for Grain Sorghum Quality Factors ${ }^{\mathrm{a}, \mathrm{b}}$

\begin{tabular}{lccccc}
\hline Factors $^{\mathbf{c}}$ & Factor 1 & Factor 2 & Factor 3 & Factor 4 & Factor 5 \\
\hline Eigenvalue & 3.46 & 1.84 & 1.18 & 1.07 & 0.87 \\
Proportion & 34.61 & 18.39 & 11.83 & 10.70 & 8.76 \\
Cumulative & 34.61 & 53.00 & 64.83 & 75.53 & 84.28 \\
$\quad$ proportion & & & & & \\
Starch & -0.13 & -0.16 & $\mathbf{0 . 9 0}$ & 0.13 & 0.03 \\
Protein & -0.004 & $\mathbf{0 . 9 0}$ & -0.03 & -0.12 & 0.02 \\
Fat & -0.002 & 0.06 & -0.13 & -0.07 & $\mathbf{0 . 9 7}$ \\
Test weight & $\mathbf{0 . 5 7}$ & $\mathbf{- 0 . 7 3}$ & 0.02 & -0.10 & -0.03 \\
Density & $\mathbf{0 . 6 4}$ & $\mathbf{- 0 . 6 7}$ & -0.13 & 0.03 & -0.04 \\
TKW & $\mathbf{0 . 6 9}$ & 0.05 & 0.24 & 0.34 & -0.04 \\
\%A & $\mathbf{0 . 7 9}$ & -0.14 & -0.30 & 0.04 & 0.19 \\
WAI & 0.05 & -0.07 & -0.06 & $\mathbf{0 . 9 5}$ & -0.06 \\
IWAR & -0.03 & -0.21 & $\mathbf{- 0 . 8 2}$ & 0.26 & 0.29 \\
MSP & $\mathbf{- 0 . 8 5}$ & 0.22 & 0.04 & 0.12 & 0.11 \\
\hline
\end{tabular}

a Factors 1-5 represent matrix compactness, matrix protein content, osmotic potential, water absorption index, and crude free fat factor, respectively.

${ }^{\mathrm{b}}$ Correlation coefficients $(r$ ) characterize the influence of each quality factor in the corresponding rotated factor. Bold entries are the most significant coefficients within each factor.

${ }^{\mathrm{c}} \mathrm{TKW}=1,000$ kernel weight, $\% \mathrm{~A}=$ percent kernel abraded, $\mathrm{WAI}=$ water absorption index, IWAR = initial water absorption rate, and MSP = moisture saturation point.

coefficients of variation. High variation in TKW may be partly due to the small sample size (2.5-3.5 g vs. $20 \mathrm{~g}$ for density). MSP had a much smaller variability than both WAI and IWAR. IWAR had the highest dispersion among factors.

Table II shows correlation coefficients $(r)$ for the quality factors studied. Test weight and absolute density were expectedly highly correlated, even with a higher coefficient $(r=0.86)$ than the one reported for maize by Dorsey-Redding et al (1991). This was attributed to differences in kernel shape between grain sorghum and corn. Sorghum, being a rounded, nearly spherical kernel, is able to arrange in a more packed fashion, leaving less void volume. Thus, differences between bulk density and absolute density are smaller for sorghum than for corn. Both test weight and absolute density were positively correlated with $\% \mathrm{~A}(r=0.52$ and $r=$ 0.62 , respectively) indicating that the denser the kernel, the softer it was.

Protein was highly negatively correlated with test weight and absolute density ( $r=-0.53$ for both factors). It seemed that the denser the kernel, the lower the protein content. In other words, a higher density did not mean more protein was present in the protein matrix. Starch is more dense than protein (Hoseney 1994) and under good growing conditions (e.g., the abundant moisture and near-normal temperatures of 1993 and 1994), more starch is deposited in kernels than protein (Bewley and Black 1985), thereby increasing kernel density but decreasing protein content. 
An inverse relationship between test weight and protein was previously reported by Deyoe (1975) in regard to the utilization of sorghum grain as animal feed. In fact, Deyoe (1975) challenged the relevance of test weight as a decisive parameter of quality, as presently used in the U.S. Standards.

TKW was moderately correlated with density $(r=0.34)$ and $\% \mathrm{~A}(r=0.32)$. Apparently, heavy kernels were denser and softer than light kernels. However, further verification is needed with respect to this statement due to relatively low $r$-values. Analysis of measurements for hybrids having more variability in density, kernel size, starch content, protein content, and kernel hardness would be appropriate.

MSP was negatively correlated with test weight $(r=-0.60)$, absolute density $(r=-0.65), \% \mathrm{~A}(r=-0.62)$, and TKW $(r=-0.45)$. According to these results, the denser and softer the kernel, the lower the MSP (the lower the amount of water needed to be absorbed to reach the saturation point). A reasonable explanation for the negative correlation between TKW and MSP is that a heavier kernel has a lower porosity than a lighter kernel, therefore water absorption is less and the MSP decreases. However, no significant correlations were observed between WAI or IWAR and TKW, test weight, or density, as could have been the case following analogous reasoning. Actually, no significant linear correlation existed among the three water absorption parameters.

Two correlations of IWAR, a positive one with fat $(r=0.32)$, and a highly negative one with starch $(r=-0.58)$, were not easily explainable. Speculatively, since starch is water-insoluble and of large molecular weight, a higher amount of starch could have resulted in a lower driving force (from an osmotic and water availability standpoint) for water uptake, thus leading to a lower IWAR.

Negative correlations of protein with TKW and starch in the study of Subramanian and Jambunathan (1981) were not observed here. Most likely, this was due to genetic differences in tested sorghum samples.

\section{Principal Component Factor Analysis}

Results of principal components analysis through the covariance matrix are shown in Table III. Two factors, derived from the orthogonal transformation of the matrix, explained $95 \%$ of the variation according to eigenvalues (Factor 1, 84\%; Factor 2, 11\%). Factor 1, which was called endosperm matrix protein composition factor, was influenced positively by test weight, density, and \%A, and influenced negatively by protein and MSP. This factor was identical to the above analysis: the denser and softer the kernel, the lower the protein content and MSP. Factor 2, which was called water absorption factor, was influenced positively by $\% \mathrm{~A}$ and IWAR, and influenced negatively by starch and MSP. These trends also were observed in Table II and indicate that softer kernels absorb water faster and require less water than harder kernels to reach a saturation point.

Table IV gives the results of principal components analysis through the correlation matrix. Five factors, derived from the orthogonal transformation of the matrix, were retained to explain $85 \%$ of the variation according to eigenvalues (Factor 1, 35\%; Factor 2, 18\%; Factor 3, 12\%; Factor 4, 11\%; Factor 5, 9\%). Factor 1, which was called matrix compactness factor, was influenced positively by TKW, absolute density, test weight, and \% A, and influenced negatively by MSP. This followed the statements already inferred from Table II. Factor 2, which was called matrix protein content factor, was influenced positively by protein, and influenced negatively by density and test weight. It also was explained through the trend derived from Table II. Factor 3, which was called water potential factor, was influenced positively by starch and influenced negatively by IWAR. Presence of greater starch within a kernel may slow absorption as water may be differentially absorbed by the various compounds within the kernel. For Factor 4, the sole influence was WAI. The sole influence in Factor 5 was crude free fat.

\section{Implications}

Inverse relationships of protein content with both test weight and absolute density found in this study confirmed previous data reported by Deyoe (1975) regarding utilization of grain sorghum as animal feed. As mentioned, Deyoe (1975) challenged the relevance of test weight as a parameter of quality (USDA 1970) because of the fact that only small differences existed between the feeding value of high and low test weight sorghum. Lack of test weight correlation with starch and crude free fat and only a moderate correlation with protein in this study seemed to support this statement. Freeman (1973) and Dorsey-Redding et al (1991) similarly concluded that test weight was a poor indicator of quality in maize.

Principal component factor analysis reinforced the relationships among quality factors derived from the correlation matrix, since the components with the highest eigenvalues (i.e., those that explained most of the variation associated with the sample set analyzed) closely followed the trends initially derived using simple correlation coefficients. Primary among the relationships were the apparent decreasing water absorption rate with increasing starch content of grain sorghum kernels, and the apparent increased water absorption rate and decreased amount of water for saturation for soft kernels. Steeping times in wet-milling would be influenced by both relationships and would require adjustment to maintain economic starch recovery. However, interaction of starch content of kernels with water absorption rate and kernel hardness needs to be better understood before recommendations can be made relative to wet-milling procedures.

\section{LITERATURE CITED}

American Association of Cereal Chemists. 1995. Approved Methods of the AACC, 9th ed. Method 76-12, approved June 1993, revised October 1994. The Association: St. Paul, MN.

ASAE. 1992. American Society of Agricultural Engineers Standards, 39th ed. S352.2. The Society: St. Joseph, MI.

AOAC. 1984. Official Methods of Analysis of the, 14th ed. Method 922.05. The Association: Washington, DC.

Bewley, J. D., and Black, M. 1985. Seeds: Physiology of Development and Germination, 2nd ed. Plenum Press: New York.

Cagampang, G. B., and Kirleis, A. W. 1984. Relationship of sorghum grain hardness to selected physical and chemical measurements of grain quality. Cereal Chem. 61:100-105.

Chung, D. S., Fan, L. T., and Shellenberger, J. A. 1961. Volume increase of wheat kernels accompanying absorption of liquid water. J. Biochem. Microbiol. Technol. Eng. 3:377-393.

CRA. 1986. Standard Analytical Methods of the Member Companies of Corn Industry Research Foundation. Method A-18, approved June 1957. Corn Refiners Association: Washington, DC.

Deyoe, C. W. 1975. Do grain standards relate to feed usage? Pages I1-I9 in: Proc. 30th Kansas Formula Feed Conf. Kansas State University: Manhattan, KS.

Dorsey-Redding, C., Hurburgh, C. R., Jr., Johnson, L. A., and Fox, S. R. 1991. Relationships among maize quality factors. Cereal Chem. 68:602-605.

Fan, L. T., Chu, P. S., and Shellenberger, J. A. 1962. Volume increase of kernels of corn and sorghum accompanying absorption of liquid water. Biotechnol. Bioeng. 4:311-322.

FGIS. 1988. Test weight per bushel apparatus. Pages 1-16 in: Grain Inspection Handbook. Book II. General Information. USDA: Washington, DC.

Freeman, J. E. 1973. Quality factors affecting value of corn for wet milling. Trans. ASAE 16:671-678.

Hoseney, R. C. 1994. Principles of Cereal Science and Technology, 2nd ed. Am. Assoc. Cereal Chem.: St. Paul, MN.

Hsu, K. H., Kim, C. J., and Wilson, L. A. 1983. Factors affecting water uptake of soybeans during soaking. Cereal Chem. 60:208-211.

Johnson, R. A., and Wichern, D. W. 1992. Applied Multivariate Statistical Analysis. Prentice-Hall: Englewood Cliffs, NJ.

Maxson, E. D., Fryar, W. B., Rooney, L. W., and Krishnaprasad, M. N. 1971. Milling properties of sorghum grain with different proportions of corneous to floury endosperm. Cereal Chem. 48:478-490. 
Munck, L., Bach Knudsen, K. E., and Axtell, J. D. 1981. Milling processes and products related to kernel morphology. Pages $200-210$ in: Proc. Int. Symp. on Sorghum Grain Quality. L.W. Rooney and D.S Murphy, eds. Int. Crops Res. Inst. Semi-Arid Tropics (ICRISAT): Patancheru, India.

Oomah, B. D., Reichert, R. D., and Youngs, C. G. 1981. A novel, multisample, tangential abrasive dehulling device (TADD). Cereal Chem. 58:392-395.

Reichert, R. D., Youngs, C. G., and Oomah, B. D. 1981. Measurement of grain hardness and dehulling quality with a multi-sample, tangential abrasive dehulling device (TADD). Pages 186-193 in: Proc. Int. Symp. on Sorghum Grain Quality. L. W. Rooney and D. S. Murphy, eds. Int. Crops Res. Inst. Semi-Arid Tropics (ICRISAT): Patancheru, India.

Serna-Saldivar, S., and Rooney, L. W. 1995. Structure and chemistry of sorghum and millets. Pages 69-124 in: Sorghum and Millets Chemistry and Technology. D.A.V. Dendy, ed. Am. Assoc. Cereal Chem.: St. Paul, MN.
Subramanian, V., Hoseney, R. C., and Bramel-Cox, P. 1994. Factors affecting the color and appearance of sorghum starch. Cereal Chem. $71: 275-278$

Subramanian, V., and Jambunathan, R. 1981. Properties of sorghum grain and their relationship to roti quality. Pages $280-288$ in: Proc. Int. Symp. on Sorghum Grain Quality. L. W. Rooney and D. S. Murphy, eds. Int. Crops Res. Inst. Semi-Arid Tropics (ICRISAT): Patancheru, India.

Thompson, R. A., and Isaacs, G. W. 1967. Porosity determinations of grains and seeds with an air-comparison pycnometer. Trans. ASAE 10:693-696.

Watson, S. A. 1970. Wet-Milling: Process and Products. Pages 602-626 in: Sorghum: Production and Utilization. S. Wall and M. Ross, eds. Avi Publishing Co.: Westport, CT.

USDA. 1970. Official Grain Standards of the United States. Consumer and Marketing Service, Grain Division. U.S. Government Printing Office: Washington, DC.

[Received March 6, 1997. Accepted September 18, 1997.] 